\title{
Sanitasi Lingkungan dan Perilaku Sehat pada Rumah Kos Mahasiswa di Lingkungan Kampus Universitas Andalas
}

\author{
Aria Gusti", Rahma Risandi \\ Departemen Kesehatan Lingkungan, Fakultas Kesehatan Masyarakat, Universitas Andalas, Jl. Perintis Kemerdekaan No.94, \\ Padang, Sumatera Barat 25171, Indonesia \\ *Corresponding author: aria.mkes@gmail.com
}

Info Artikel : Diterima 21 Agustus 2020 ; Disetujui 17 Maret 2021 ; Publikasi 1 Oktober 2021

Cara sitasi (Vancouver): Gusti A, Risandi R. Sanitasi Lingkungan dan Perilaku Sehat pada Rumah Kos Mahasiswa di Lingkungan Kampus Universitas Andalas. Jurnal Kesehatan Lingkungan Indonesia [Online]. 2021 Oct;20(2):74-81. https://doi.org/10.14710/jkli.20.2.74-81.

\begin{abstract}
ABSTRAK
Latar belakang: Sanitasi lingkungan yang buruk dapat mempengaruhi motivasi belajar mahasiswa, menurunkan konsentrasi belajar dan aktivitas sehari-hari di rumah kos mahasiswa. Penelitian ini bertujuan menilai fasilitas sanitasi lingkungan dan perilaku sehat mahasiswa di rumah kos sekitar kampus Universitas Andalas.

Metode: Menggunakan pendekatan studi kasus, studi ini fokus pada kos-kosan mahasiswa di lingkungan kampus Universitas Andalas di Kecamatan Pauh Kota Padang. Sebanyak 96 rumah kos mahasiswa menjadi sampel dalam penelitian ini. Instrumen penelitian yang digunakan berupa formulir observasi berisi variabelvariabel yang akan diteliti yaitu kondisi rumah, penyediaan air bersih, saluran pembuangan air limbah, tempat pembuangan sampah dan jamban yang digunakan oleh penghuni asrama ataupun kos mahasiswa. Data diperoleh dengan wawancara langsung terhadap penghuni kos dan observasi lapangan.

Hasil: Sebagian besar (91,7\%) rumah kos mahasiswa Universitas Andalas berlantai ubin/keramik. Lebih dari setengah $(60,4 \%)$ kamar kos tidak memiliki ventilasi. Air minum isi ulang menjadi pilihan dari hampir semua (96,9\%) rumah kos di di Lingkungan Universitas Andalas. Semua rumah kos di lingkungan Universitas Andalas memiliki jamban. Lebih dari setengah (61,5\%) rumah kos mahasiswa di di Lingkungan Universitas Andalas terdapat vektor penyebar penyakit baik berupa lalat, nyamuk, tikus, maupun kecoa. Hampir semua (91,7\%) penghuni kos di di Lingkungan Universitas Andalas tidak memiliki kebiasaan merokok.

Simpulan: Rumah kos mahasiswa di di Lingkungan Universitas Andalas yang tersebar di 3 kelurahan di Kecamatan Pauh Kota Padang hampir semuanya memenuhi persyaratan rumah sehat.
\end{abstract}

Kata kunci: sanitasi; lingkungan; rumah kos; mahasiswa

\section{ABSTRACT}

Title: Environmental Sanitation of Student Boarding Houses at Universitas Andalas

Background: Poor environmental sanitation can affect student motivation, reduce concentration of learning and daily activities at the student boarding house. This study aims to assess the availability of environmental sanitation facilities and the behavior of students' environmental sanitation in terms of utilizing available environmental sanitation facilities.

Method: Using a case study approach, this study focuses on student boarding at the Andalas University campus environment in Pauh District, Padang City. The research instrument used was in the form of an observation form containing variables to be examined, namely the condition of housing, water supply, sewerage, garbage disposal and latrines used by residents of the dormitory or boarding students. Data obtained by direct interviews with boarders and field observations. 
Result: Most Andalas University boarding house students have tile / ceramic floors. More than half of the boarding rooms do not have ventilation. Refill drinking water is the choice of almost all boarding houses in Andalas University. All boarding houses in the Andalas University environment have latrines. More than half of the student boarding houses in Andalas University, there are disease-spreading vektors in the form of flies, mosquitoes, rats and cockroaches. Almost all boarders in Andalas University are not smoking.

Conclusion: The boarding houses of students at Andalas University are spread over 3 villages in Pauh District, Padang City, almost all of them fulfill the requirements of a healthy home.

Keywords:sanitation; environmental; boarding house; students

\section{PENDAHULUAN}

Persentase rumah sehat di Kecamatan Pauh sebesar $61,19 \%$ dari 8.477 rumah yang ada. Penduduk yang memiliki akses ke jamban sehat sebesar $70,44 \%$. Jumlah sumur gali sebanyak 241 buah yang di manfaatkan oleh 1.889 orang. Penduduk yang mempunyai akses berkelanjutan terhadap sarana air bersih yang layak sebesar $78,31 \%{ }^{1}$

Berdasarkan data yang diperoleh dari Kecamatan Pauh bahwa penyakit Infeksi Saluran Pernapasan Akut (ISPA) menempati urutan tertinggi dari 10 penyakit terbanyak tahun 2018 yaitu sebanyak 6.865 penderita. Penyakit Infeksi Saluran Pernapasan Akut (ISPA) merupakan salah satu penyakit yang diakibatkan oleh sanitasi yang buruk. Sedangkan penyakit diare yang juga merupakan salah satu penyakit berbasis lingkungan menempati urutan kedelapan yaitu sebanyak 380 penderita. $^{2}$

Mahasiswa Universitas Andalas yang berasal dari luar Kota Padang kebanyakan kos di lingkungan kampus yang berada di Kecamatan Pauh. Sanitasi lingkungan masih menjadi permasalahan di sebagian rumah kos. Sampah yang berserakan ditemui di lingkungan rumah kos maupun selokan-selokan yang menimbulkan bau yang tidak sedap. Jamban yang tidak sesuai standar kesehatan, air yang kurang bersih, dan ruangan yang sempit menurunkan konsentrasi belajar dan mengganggu aktivitas sehari-hari mahasiswa penghuni rumah kos di lingkungan Universitas Andalas.

Penelitian ini bertujuan menilai sanitasi lingkungan rumah kos dan perilaku sehat mahasiswa di Universitas Andalas. Penelitian ini menggunakan pendekatan studi kasus, studi ini akan fokus pada koskosan mahasiswa di lingkungan kampus Universitas Andalas Limau Manis.

\section{MATERI DAN METODE}

Penelitian ini dilakukan di rumah kos mahasiswa di Lingkungan Universitas Andalas. Populasi penelitian adalah semua asrama dan rumah kos mahasiswa di lingkungan Universitas Andalas Kecamatan Pauh Kota Padang yaitu sebanyak 63 rumah/pondokan. Semua populasi dijadikan sampel penelitian.

Instrumen penelitian yang digunakan adalah kuesioner perilaku sehat dan formulir observasi berisi varibel-variabel yang akan diteliti yaitu kondisi rumah, penyediaan air bersih, saluran pembuangan air limbah, tempat pembuangan sampah dan jamban yang digunakan oleh penghuni asrama ataupun rumah kos mahasiswa. Data diperoleh dengan wawancara langsung dengan penghuni kos dan observasi lapangan.

Pengolahan data digunakan dengan sistem komputer untuk memperoleh nilai statistik dalam bentuk diagram dari data hasil interview dan observasi. Penyajian data disajikan dalam bentuk tabel distribusi disertai penjelasan-penjelasan. Analisis univariat dilakukan terhadap tiap variabel dari hasil penelitian berupa distribusi frekuensi variabel tunggal sesuai tujuan penelitian.

\section{HASIL DAN PEMBAHASAN \\ Karakteristik Responden}

Tabel 1. Karakteristik Responden

\begin{tabular}{llllr}
\hline \multirow{2}{*}{\begin{tabular}{c} 
Jenis Rumah \\
\multicolumn{1}{c}{ Kos }
\end{tabular}} & \multicolumn{4}{c}{ Kelurahan } \\
\cline { 2 - 5 } & $\begin{array}{c}\text { Cupak } \\
\text { Tangah }\end{array}$ & Kapalo Koto & \multicolumn{1}{c}{$\begin{array}{c}\text { Limau } \\
\text { Manis }\end{array}$} & Jumlah \\
\hline - Laki-laki & $5(16,1 \%)$ & $8(21,6 \%)$ & $9(32,1 \%)$ & $22(22,9 \%)$ \\
- Perempuan & $26(83,9 \%)$ & $29(78,4 \%)$ & $19(67,9 \%)$ & $74(77,1 \%)$ \\
Jumlah & $31(100 \%)$ & $37(100 \%)$ & $28(100 \%)$ & $96(100 \%)$ \\
\hline
\end{tabular}

Lebih dari setengah rumah kos yang disurvei merupakan rumah kos perempuan, yaitu sebesar $77,1 \%$. Paling besar persentase rumah kos perempuan adalah di Kelurahan Cupak Tangah sebesar 83,9\%.

\section{Komponen Rumah}

Tabel 2 menunjukkan bahwa sebagian besar rumah kos mahasiswa Universitas Andalas berlantai ubin/keramik $(91,7 \%)$. Kebanyakan memiliki jendela yang mudah dibuka, yaitu sebesar 90,6\% meskipun masih ada $8,3 \%$ memiliki jendela tetapi tidak bisa 
ditutup dan dibuka. Masih ada sebesar 15,6\% rumah kos yang memiliki langit-langit yang kotor dan sulit untuk dibersihkan. 93,8\% dari rumah kos mahasiswa Universitas Andalas memiliki dinding permanen/ tembok/ pasangan batu diplester. Lebih dari separoh kamar kos tidak memiliki ventilasi $(60,4 \%)$. Ada $38,5 \%$ rumah kos memiliki ventilasi, namun luasnya masih kurang dari 10\% dari luas lantai. Tidak sampai setengah dari rumah kos yang memiliki pintu yang kokoh $(33,3 \%)$. Ada 54,2\% dari rumah kos walaupun memiliki pintu yang tidak kokoh tetapi sudah dilengkapi dengan kunci. Sementara yang memiliki pintu yang tidak kokoh dan tidak dilengkapi kunci adalah sebesar $12,5 \%$.

Tabel 2. Komponen Rumah Kos Mahasiswa di Lingkungan Universitas Andalas

\begin{tabular}{|c|c|c|c|c|}
\hline Komponen Rumah & $\begin{array}{l}\text { Cupak } \\
\text { Tangah }\end{array}$ & $\begin{array}{c}\text { Kapalo } \\
\text { Koto }\end{array}$ & $\begin{array}{l}\text { Limau } \\
\text { Manis }\end{array}$ & Jumlah \\
\hline \multicolumn{5}{|l|}{ Lantai : } \\
\hline $\begin{array}{l}\text { - Papan/tanah plesteran yang retak } \\
\text { dan berdebu }\end{array}$ & $1(3,2 \%)$ & 0 & $1(3,2)$ & $2(2,1 \%)$ \\
\hline - Semen licin tanpa ubin/keramik & $3(9,7 \%)$ & $2(5,4 \%)$ & $1(3,2 \%)$ & $6(6,3 \%)$ \\
\hline - Ubin/keramik & $27(87,1 \%)$ & $35(94,6 \%)$ & $26(92,6 \%)$ & $88(91,7 \%)$ \\
\hline \multicolumn{5}{|l|}{ Jendela Kamar : } \\
\hline - Tidak ada & $1(3,2 \%)$ & 0 & 0 & $1(1,0 \%)$ \\
\hline $\begin{array}{l}\text { - Ada, tapi tidak bisa } \\
\text { dibuka/ditutup }\end{array}$ & $4(12,9 \%)$ & $3(8,1 \%)$ & $1(3,6 \%)$ & $8(8,3 \%)$ \\
\hline - Ada, bisa dibuka/ditutup & $26(83,9 \%)$ & $34(91,9 \%)$ & $27(96,4 \%)$ & $87(90,6 \%)$ \\
\hline \multicolumn{5}{|l|}{ Langit-langit : } \\
\hline - Tidak ada & 0 & 0 & 0 & 0 \\
\hline - Ada, kotor dan sulit dibersihkan & $6(19,4 \%)$ & $4(10,8 \%)$ & $5(17,9 \%)$ & $15(15,6 \%)$ \\
\hline $\begin{array}{l}\text { - Ada, bersih dan mudah } \\
\text { dibersihkan }\end{array}$ & $25(80,6 \%)$ & $33(89,2 \%)$ & $23(82,1 \%)$ & $81(84,4 \%)$ \\
\hline \multicolumn{5}{|l|}{ Dinding : } \\
\hline $\begin{array}{l}\text { - Bukan tembok/terbuat dari } \\
\text { anyaman bamboo/kayu/triplek }\end{array}$ & $1(3,2 \%)$ & $1(, 7 \%)$ & 0 & $2(2,1 \%)$ \\
\hline $\begin{array}{l}\text { - Semi permanen/setengah } \\
\text { tembok/pasangan bata/batu yang } \\
\text { diplester }\end{array}$ & $1(3,2 \%)$ & $2(5,4 \%)$ & $1(3,6 \%)$ & $4(4,2 \%)$ \\
\hline $\begin{array}{l}\text { - Permanen/tembok/pasangan batu } \\
\text { yang diplester }\end{array}$ & $29(93,5 \%)$ & $34(91,9 \%)$ & $27(6,4 \%)$ & $90(93,8 \%)$ \\
\hline \multicolumn{5}{|l|}{ Ventilasi : } \\
\hline - Tidak ada & $18(58,1 \%)$ & $26(70,3 \%)$ & $14(50 \%)$ & $58(60,4 \%)$ \\
\hline $\begin{array}{l}\text { - Ada, luas ventilasi permanen } \\
<10 \% \text { luas lantai }\end{array}$ & $13(41,9 \%)$ & $11(29,7 \%)$ & $13(46,4 \%)$ & $37(38,5 \%)$ \\
\hline $\begin{array}{l}\text { - Ada, luas ventilasi permanen } \\
>10 \% \text { luas lantai }\end{array}$ & 0 & 0 & $1(3,6 \%)$ & $1(1 \%)$ \\
\hline \multicolumn{5}{|l|}{ Pintu : } \\
\hline $\begin{array}{l}\text { - Tidak kokoh dan tidak dilengkapi } \\
\text { kunci }\end{array}$ & $6(19,4 \%)$ & $5(13,5 \%)$ & $1(3,6 \%)$ & $12(12,5 \%)$ \\
\hline $\begin{array}{l}\text { - Tidak kokoh, tapi ada dilengkapi } \\
\text { kunci }\end{array}$ & $11(35,5 \%)$ & $18(48,6 \%)$ & $23(82,1 \%)$ & $52(54,2 \%)$ \\
\hline - Kokoh & $14(45,2 \%)$ & $14(37,8 \%)$ & $4(14,3 \%)$ & $32(33,3 \%)$ \\
\hline
\end{tabular}

\section{Fasilitas Sanitasi}

Pada tabel 3 terlihat bahwa air minum isi ulang menjadi pilihan dari hampir semua rumah kos di di Lingkungan Universitas Andalas, yaitu sebesar 96,9\%. Sementara sisanya mengkonsumsi air PDAM $(2,1 \%)$ dan air dari sumur yang terlindung $(1 \%)$.
Saluran pembuangan air limbah di rumah kos di di Lingkungan Universitas Andalas sebagian besar, yaitu $91,7 \%$ berupa saluran tertutup dan mengalir dengan lancar. Namun, masih ada 7,3\% lainnya yang tidak memiliki saluran pembuangan air limbah sehingga dibuang langsung ke sungai atau selokan. Disamping itu masih ada 1 rumah kos yang memiliki 
saluran tertutup tapi airnya tidak mengalir dengan lancar.

Seluruh rumah kos di di Lingkungan Universitas Andalas memiliki jamban. Hampir semuanya (95,8\%) berupa jamban yang dipakai bersama oleh penghuni rumah kos. Hanya 4,2\% dari rumah kos yang disurvei yang memiliki jamban di tiap kamar kos. Tipe jamban kosan mahasiswa di Lingkungan Universitas Andalas hampir semuanya leher angsa dengan septic tank. Hanya 4 rumah kos $(4,2 \%)$ yang masih memakai jamban cemplung namun sudah memakai septic tank.

Lebih dari setengah (61,5\%) rumah kos mahasiswa di di Lingkungan Universitas Andalas terdapat vektor penyebar penyakit baik berupa lalat, nyamuk, tikus, maupun kecoa. Keberadaan vektor terbanyak ditemui di kelurahan Kapalo Koto, yaitu sebesar $70,3 \%$.

Fasilitas tempat sampah yang kedap air/tertutup dan tidak mudah berkarat ditemui pada 33,3\% rumah kos mahasiswa di di Lingkungan Universitas Andalas. Sementara yang terbanyak adalah rumah kos dengan fasilitas tempat sampah tidak kedap air/ tidak tertutup/ mudah berkarat, yaitu sebesar 54,2\%. Hal memprihatinkan adalah masih ada 12,5\% rumah kos yang tidak memiliki tempat sampah.

Fasilitas sanitasi rumah kos mahasiswa di di Lingkungan Universitas Andalas terangkum pada tabel 3 .

Tabel 3. Fasilitas Sanitasi Rumah Kos Mahasiswa Di Lingkungan Universitas Andalas

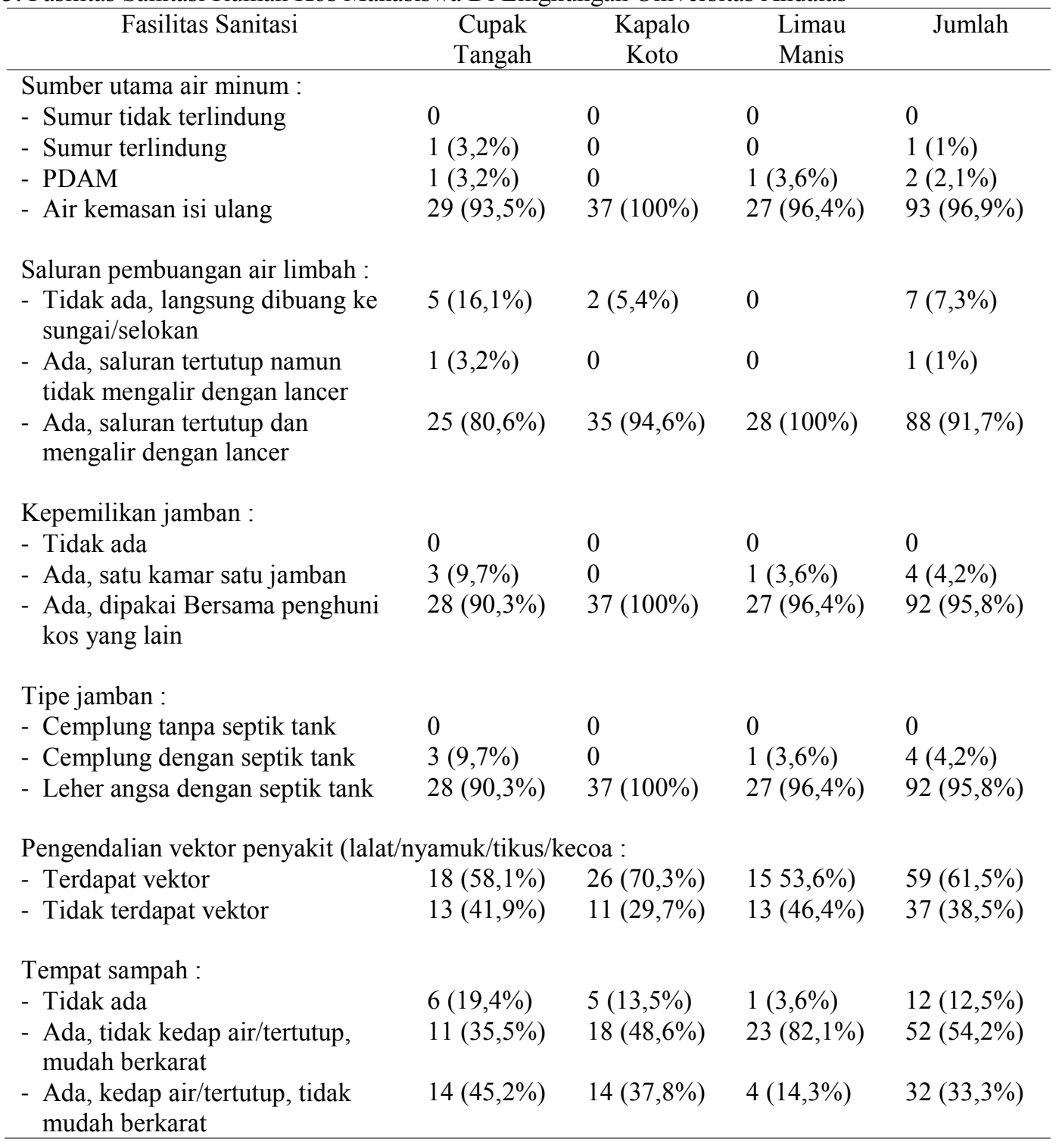

\section{Perilaku Penghuni}

Kebiasaan membuka jendela tiap hari sebagaimana terlihat pada tabel 4 dilakukan oleh kurang dari setengah penghuni rumah kos $(35,4 \%)$, yang membuka jendela kadang-kadang $50 \%$ dan yang tidak pernah membuka jendela kamarnya sebanyak $14,6 \%$.

Lebih dari setengah penghuni kos membersihkan kamarnya setiap hari $(58,3 \%)$ dan yang tidak pernah membersihkan kamarnya sebanyak 26\%. Setengah responden mengganti sprei dan sarung bantal sebulan 
sekali, dua minggu sekali $35,3 \%$, dan hanya $14,6 \%$ yang mengganti sprei dan sarung bantal tiapminggu.

Kebiasan menguras bak mandi dilakukan oleh sebagian besar responden setiap minggu, yaitu sebesar $75 \%$. Sebagian besar responden $(84,4 \%)$ membuang sampah ke kontainer/ TPS/ diangkut tukang sampah dan sisanya mengelola sampah dengan cara dibakar. Sebanyak $82,3 \%$ responden selalu mencuci tangan pakai sabun setelah BAB maupun sebelum/sesudah makan dan sisanya kadang-kadang mencuci tangan pakai sabun.

Sebanyak 91,7\% penghuni rumah kos mahasiswa di Lingkungan Universitas Andalas tidak memiliki kebiasaan merokok. Mahasiswa penghuni kos yang merokok hanya sebesar $6,3 \%$ dan yang kadang-kadang merokok sebesar 2,1\%.

Perilaku sehat mahasiswa penghuni rumah kos di di Lingkungan Universitas Andalas dapat dilihat pada tabel 4.

Tabel 4. Perilaku Penghuni Rumah Kos Mahasiswa Di Lingkungan Universitas Andalas

\begin{tabular}{|c|c|c|c|c|}
\hline Perilaku Penghuni & $\begin{array}{c}\text { Cupak } \\
\text { Tangah }\end{array}$ & Kapalo Koto & $\begin{array}{l}\text { Limau } \\
\text { Manis }\end{array}$ & Jumlah \\
\hline $\begin{array}{l}\text { Membuka jendela kamar : } \\
\text { - Tidak pernah } \\
\text { - Kadang-kadang } \\
\text { - Tiap hari }\end{array}$ & $\begin{array}{l}7(22,6 \%) \\
11(35,5 \%) \\
13(41,9 \%)\end{array}$ & $\begin{array}{l}6(16,2 \%) \\
18(48,6 \%) \\
13(35,1 \%)\end{array}$ & $\begin{array}{l}1(3,6 \%) \\
19(67,9 \%) \\
8(28,6 \%)\end{array}$ & $\begin{array}{l}14(14,6 \%) \\
48(50 \%) \\
34(35,4 \%)\end{array}$ \\
\hline $\begin{array}{l}\text { Membersihkan kamar : } \\
\text { - Tidak pernah } \\
\text { - Kadang-kadang } \\
\text { - Tiap hari }\end{array}$ & $\begin{array}{l}2(6,5 \%) \\
4(12,9 \%) \\
25(80.6 \%)\end{array}$ & $\begin{array}{l}11(29,7 \%) \\
7918,9 \%) \\
19(51,4 \%)\end{array}$ & $\begin{array}{l}12(42,9 \% \\
4(14,3 \%) \\
12(42,9 \%)\end{array}$ & $\begin{array}{l}25(26 \%) \\
5(15,6 \%) \\
56(58,3 \%)\end{array}$ \\
\hline $\begin{array}{l}\text { Mengganti sprei dan sarung bant } \\
\text { - Satu bulan sekali } \\
\text { - Dua minggu sekali } \\
\text { - Satu minggu sekali }\end{array}$ & $\begin{array}{l}: \\
15(48,4 \%) \\
12(38,7 \% 0 \\
4(12,9 \%)\end{array}$ & $\begin{array}{l}18(48,6 \%) \\
15(40,5 \%) \\
4(10.8 \%)\end{array}$ & $\begin{array}{l}15(53,6 \%) \\
7(255) \\
6(21,4 \%)\end{array}$ & $\begin{array}{l}48(50 \%) \\
34(35,3 \%) \\
14(14,6 \%)\end{array}$ \\
\hline $\begin{array}{l}\text { Menguras bak mandi : } \\
\text { - Tidak pernah } \\
\text { - Satu bulan sekali } \\
\text { - Dua minggu sekali } \\
\text { - Satu minggu sekali }\end{array}$ & $\begin{array}{l}1(3,2 \%) \\
3(9,7 \%) \\
7(22,6 \%) \\
20(64,5 \%)\end{array}$ & $\begin{array}{l}0 \\
3(8,1 \%) \\
5(13,5 \% 0 \\
29(78,4 \%)\end{array}$ & $\begin{array}{l}1(3,6 \%) \\
1(3,6 \% 0 \\
310,7 \%) \\
23(82,1 \%)\end{array}$ & $\begin{array}{l}2(2,1 \%) \\
7(7,3 \%) \\
15(15,6 \%) \\
72(75 \%)\end{array}$ \\
\hline $\begin{array}{l}\text { Membuang sampah : } \\
\text { - Dibuang ke sungai/ } \\
\text { selokan/lahan kosong } \\
\text { - Dibakar } \\
\text { - Ditimbun } \\
\text { - Dibuang ke container/ } \\
\text { TPS/diangkut tukang sampah }\end{array}$ & $\begin{array}{l}0 \\
4(12,9 \%) \\
0 \\
27(87,1 \%)\end{array}$ & $\begin{array}{l}3(8,1 \%) \\
0 \\
34(91,9 \%)\end{array}$ & $\begin{array}{l}0 \\
8(28,6 \% 0 \\
0 \\
20(71,4 \%)\end{array}$ & $\begin{array}{l}0 \\
15(15,6 \%) \\
0 \\
81(84,4 \%)\end{array}$ \\
\hline $\begin{array}{l}\text { Mencuci tangan pakai sabun sest } \\
\text { - Tidak pernah } \\
\text { - Jarang } \\
\text { - Selalu }\end{array}$ & $\begin{array}{l}\text { lah BAB dan } \\
0 \\
4(12,9 \%) \\
27(87,1 \% 0\end{array}$ & $\begin{array}{l}\text { elum/sesudah } \\
8(21,6 \%) \\
29(78,4 \%)\end{array}$ & $\begin{array}{l}\text { nakan : } \\
0 \\
5(17,9 \%) \\
23(82,1 \%)\end{array}$ & $\begin{array}{l}0 \\
17(17,7 \%) \\
79(82,3 \%)\end{array}$ \\
\hline $\begin{array}{l}\text { Kebiasaan merokok: } \\
\text { - Ya } \\
\text { - Kadang-kadang } \\
\text { - Tidak }\end{array}$ & $\begin{array}{l}2(6,5 \% 0 \\
0 \\
29(93,5 \%)\end{array}$ & $\begin{array}{l}2(5,4 \%) \\
1(2,7 \%) \\
34(91,9 \%)\end{array}$ & $\begin{array}{l}2(7,1 \%) \\
1(3,6 \%) \\
25(89,3 \%)\end{array}$ & $\begin{array}{l}6(6,3 \%) \\
2(2,1 \%) \\
88(91,7 \%)\end{array}$ \\
\hline
\end{tabular}

\section{Lingkungan Fisik}

Tabel 5 menampilkan hasil observasi lingkungan fisik rumah kos dinilai berdasarkan pencahayaan dan kepadatan hunian kamar. Pada tabel 5 terlihat sebesar 91,7\% rumah kos mahasiswa Universitas Andalas memiliki pencahayaan yang terang dan tidak silau sehingga dapat dipergunakan untuk membaca dengan normal. Pencahayaan yang kurang terang sehingga kurang jelas dipergunakan untuk membaca dengan normal ditemui pada 8 rumah kos $(8,3 \%)$. Rumah kos dengan pencahayaan yang tidak terang sehingga tidak dapat digunakan untuk membaca tidak ada ditemukan. 
Luas ruang tidur yang kurang dari $8 \mathrm{~m}^{2}$ hanya ditemui pada $28,1 \%$ rumah kos. Artinya sebanyak $71,9 \%$ rumah kos mahasiswa di lingkungan
Universitas Andalas memenuhi persyaratan kepadatan kamar, yaitu luas ruang tidur minimal $8 \mathrm{~m}^{2}$ dihuni maksimal 2 orang.

Tabel 5. Lingkungan Fisik Rumah Kos Mahasiswa Di Lingkungan Universitas Andalas

\begin{tabular}{|c|c|c|c|c|}
\hline Lingkungan Fisik & $\begin{array}{l}\text { Cupak } \\
\text { Tangah }\end{array}$ & Kapalo Koto & $\begin{array}{l}\text { Limau } \\
\text { Manis }\end{array}$ & Jumlah \\
\hline \multicolumn{5}{|l|}{ Pencahayaan kamar: } \\
\hline $\begin{array}{l}\text { - Tidak Terang, tidak dapat } \\
\text { dipergunakan untuk membaca }\end{array}$ & 0 & 0 & 0 & 0 \\
\hline $\begin{array}{l}\text { - Kurang terang, kurang jelas } \\
\text { dipergunakan untuk membaca } \\
\text { dengan normal }\end{array}$ & $1(3,2 \%)$ & $3(8,1 \%)$ & $4(14,3 \% 0$ & $8(8,3 \% 0$ \\
\hline $\begin{array}{l}\text { - Terang dan tidak silau } \\
\text { sehingga dapat dipergunakan } \\
\text { untuk membaca dengan } \\
\text { normal }\end{array}$ & $30(96,8 \%)$ & $34(91,9 \%)$ & $24(85,7 \%)$ & $88(91,7 \%)$ \\
\hline \multicolumn{5}{|l|}{ Kepadatan kamar: } \\
\hline - Luas ruang tidur $<8 \mathrm{~m}^{2}$ & $6(19,4 \% 0$ & $10(27 \%)$ & $11(39,3 \% 0$ & $27(28,1 \% 0$ \\
\hline $\begin{array}{l}\text { - Luas ruang tidur minimal } 8 \\
\mathrm{~m}^{2} \text { dihuni maksimal } 2 \text { orang }\end{array}$ & $25(80,6 \% 0$ & $27(73 \% 0$ & $17(60,7 \%)$ & $69(71,9 \%)$ \\
\hline
\end{tabular}

Sebagian besar (92,7\%) rumah kos mahasiswa di lingkungan Universitas Andalas dari komponen rumah sudah memenuhi syarat rumah sehat. Hampir semua rumah kos memiliki jendela yang mudah dibuka dan memiliki dinding permanen/ tembok/ pasangan batu diplester. Kondisi ini memenuhi persyaratan bahwa dinding harus mampu menahan gangguan alam seperti angin kencang, hujan, dan panas, agar tidak mengganggu aktivitas penghuni di dalam ruang. ${ }^{3}$

Namun, lebih dari setengah kamar kos tidak memiliki ventilasi. Ada rumah kos memiliki ventilasi, namun luasnya masih kurang dari $10 \%$ dari luas lantai. $^{4}$ Fungsi dari ventilasi adalah agar dimungkinkan masuknya cahaya dan udara alami yang dibutuhkan untuk kesehatan dan kenyamanan penghuni rumah, melalui penggantian udara yang mengandung carbon (CO2) yang dikeluarkan oleh manusia, dengan udara segar yang baru dan mengandung oksigen (O2) untuk dihisap oleh manusia secara berkesinambungan. ${ }^{3}$ Ventilasi yang tidak mencukupi akan menyebabkan kelembaban udara di dalam ruangan naik. ${ }^{5}$ Kelembaban tinggi merupakan media yang baik untuk bakteri-bakteri, patogen. ${ }^{5}$

Tidak sampai setengah dari rumah kos yang memiliki pintu yang kokoh. Kondisi ini sangat riskan karena umumnya tempat seperti kos-kosan dan kontrakan sering ditinggal oleh pemiliknya dan itu membuat tempat kos menjadi tidak aman dan rawan kemalingan. $^{5}$

Fasilitas rumah kos mahasiswa di lingkungan Universitas Andalas sebagian besar (88,5\%) sudah memenuhi syarat rumah sehat. Air minum isi ulang menjadi pilihan dari hampir seluruh rumah kos di lingkungan Universitas Andalas. Sama halnya dengan di Institut Pertanian Bogor bahwa 90,4\% dari mahasiswa mengkonsumsi air minum dalam kemasan tinggal di rumah kos atau kontrakan. ${ }^{6}$

Saluran pembuangan air limbah di rumah kos di di lingkungan Universitas Andalas sebagian besar berupa saluran tertutup dan mengalir dengan lancar. Kondisi ini sudah memenuhi persyaratan bahwa limbah cair yang berasal dari rumah tidak mencemari sumber air, tidak menimbulkan bau dan tidak mencemari permukaan tanah. 5,8

Seluruh rumah kos di lingkungan Universitas Andalas memiliki jamban. Hasil ini jauh lebih baik dibanding rumah kos mahasiswa di Padukuhan Karangmalang Yogyakarta hanya $70 \%$ yang memiliki jamban sehat. ${ }^{7}$ Hampir semua jamban $(95,8 \%)$ di rumah kos tersebut berupa jamban yang dipakai bersama oleh penghuni rumah kos.

Lebih dari setengah rumah kos mahasiswa di lingkungan Universitas Andalas terdapat vektor penyebar penyakit baik berupa lalat, nyamuk, tikus, maupun kecoa. Rumah kos yang sehat harus terbebas dari binatang penyebar penyakit. ${ }^{4}$ Penghuni dan pemilik kos harus mengendalikan keberadaan vektor penyebar penyakit tersebut. Pengendalian vektor bisa dilakukan dengan pengubahan lingkungan agar vektor tidak dapat berkembangbiak, istirahat, ataupun menggigit. Misalnya dengan Pembersihan Sarang Nyamuk (PSN) dan membersihkan saluran air menggenang yang dapat menjadi tempat berkembangbiak nyamuk penular penyakit. ${ }^{9}$

Fasilitas tempat sampah yang kedap air/tertutup dan tidak mudah berkarat ditemui pada 33,3\% rumah kos mahasiswa di Lingkungan Universitas Andalas. Hal yang memprihatinkan adalah masih ada 12,5\% rumah kos yang tidak memiliki tempat sampah. Jika hal ini dibiarkan, maka akan merugikan masyarakat yang tinggal disekitarnya, karena dari segi kesehatan dapat menimbulkan penyakit apabila dibuang 
sembarangan. Sampah yang tercecer ke dalam saluran air akan menyumbat aliran air sehingga dapat menimbulkan banjir pada musim hujan. ${ }^{8}$ Pengelolaan sampah yang tidak tepat dapat berdampak buruk bagi kesehatan manusia dan penyebaran penyakit menular. ${ }^{11,12}$

Hampir semua $(94,8 \%)$ penghuni rumah kos mahasiswa di lingkungan Universitas Andalas mempunyai perilaku sehat. Kebiasaan membuka jendela tiap hari dilakukan oleh kurang dari setengah penghuni rumah kos. Kondisi ini cukup memprihatinkan karena kebiasaan membuka jendela akan memudahkan sinar matahari masuk kedalam rumah dan membuka jendela setiap hari pada pagi hingga sore hari sangat penting untuk pertukaran udara. ${ }^{9}$ Paparan cahaya selama siang hari memiliki efek memengaruhi durasi dan kualitas tidur, yang kemudian dapat berdampak lebih jauh pada faktor kesehatan lainnya. Penelitian terdahulu menunjukkan bahwa kurang tidur dan kualitas tidur yang berkurang memiliki segudang konsekuensi kesehatan dan keselamatan. $^{12,13}$

Kebiasan menguras bak mandi dilakukan oleh sebagian besar responden setiap minggu. Menguras bak mandi minimal seminggu sekali diharapkan dapat memutus siklus vektor penyebar penyakit demam berdarah. $^{16}$ Muda dan Haqi berdasarkan hasil penelitiannya di Surabaya menyatakan bahwa terdapat hubungan yang signifikan antara menguras bak mandi minimal seminggu sekali dengan keberadaan jentik. ${ }^{10}$

Kebanyakan penghuni rumah kos di lingkungan Universitas Andalas selalu mencuci tangan pakai sabun setelah buang air besar maupun sebelum/sesudah makan dan sisanya kadang-kadang mencuci tangan pakai sabun. Kebiasaan baik ini perlu dipertahankan dan terus menerus dipromosikan kepada seluruh penghuni kos dan masyarakat sekitarnya. Tidak ada keraguan bahwa kebersihan pribadi termasuk mencuci tangan menurunkan angka kejadian penyakit menular. ${ }^{15,16}$

Lingkungan rumah kos mahasiswa di lingkungan Universitas Andalas hampir semuanya (94,8\%) sudah memenuhi syarat rumah sehat. Sebagian besar rumah kos mahasiswa Universitas Andalas memiliki pencahayaan yang terang dan tidak silau sehingga dapat dipergunakan untuk membaca dengan normal. Pencahayaan yang normal menyebabkan mata tidak cepat lelah. Pencahayaan yang baik berhubungan dengan kenyamanan belajar. ${ }^{11}$ Ada pengaruh signifikan pencahayaan dengan konsentrasi dan prestasi belajar mahasiswa. ${ }^{18,19}$

Sebagian besar rumah kos mahasiswa di lingkungan Universitas Andalas memenuhi persyaratan kepadatan kamar, yaitu luas ruang tidur minimal $8 \mathrm{~m}^{2}$ dan dihuni maksimal oleh 2 orang. Rumah dengan kondisi hunian yang tidak padat dapat menjaga suhu udara dalam rumah tetap normal. ${ }^{9,22}$ Semakin padat penghuni rumah, maka perpindahan penyakit khususnya penyakit melalui udara akan semakin mudah dan cepat. ${ }^{24,25}$

\section{SIMPULAN}

Rumah kos mahasiswa di Lingkungan Universitas Andalas yang tersebar di 3 kelurahan di Kecamatan Pauh Kota Padang hampir semuanya telah memenuhi persyaratan rumah sehat. Baik dari komponen rumah, fasilitas sanitasi, perilaku penghuni, dan lingkungan fisik. Namun masih ada ditemui syarat rumah sehat yang masih rendah persentasenya yaitu ventilasi kamar, kebiasaan membuka jendela, dan keberadaan vektor penyebar penyakit. Perlu diberikan pemahaman kepada pemilik dan penghuni kos tentang pentingnya ventilasi kamar yang memenuhi syarat, membuka jendela kamar di siang hari, dan mengendalikan vektor penyebar penyakit.

\section{DAFTAR PUSTAKA}

1. Dinas Kesehatan Kota Padang. Profil kesehatan kota padang. 2017

2. Badan Pusat Statistik Kota Padang. Kecamatan Pauh Dalam Angka 2018.

3. Kementerian Pekerjaan Umum. Modul Rumah Sehat. 2011. 93 p.

4. Depkes RI. Keputusan Menteri Kesehatan RI No.829/Menkes/SK/VII/1999 tentang Persyaratan Kesehatan Rumah. 1999.

5. Kaczmarek A, Wesołowska M. Factors Affecting Humidity Conditions of a Face Wall Layer of a Heated Building. Procedia Eng [Internet]. 2017;193:20510.https://doi.org/10.1016/j.proeng.2017.06.205

6. Anhar A. Studi tentang Sanitasi Lingkungan Kost Mahasiswa di Kelurahan Mangasa Kota Makassar Tahun 2010. FKM UIN Alaudin, Makasar.

7. Bagus FS, Rifani MA, Subekti M. Rancang Bangun Prototype Smart E-Kost. J Autocracy. 2015;2(1):19-25.

8. Iffatunnisa A. Analisis Willingness to Pay dan Faktor-Faktor yang Mempengaruhi Mahasiswa Institut Pertanian Bogor dalam Mengkonsumsi Air Minum di Kampus. Institut Pertanian Bogor; 2018.

9. $\mathrm{K}$ faris \& Alemayehu. Human and Other Liquid Waste Management. Ethiop public Heal Train Initiat. 2002;(November):19.

10. Ariani L. Faktor-Faktor Yang Mempengaruhi Perilaku Hidup Bersih Dan Sehat Pada Mahasiswa Kos Di Padukuhan Karangmalang Yogyakarta. Jurkessia. 2018; VIII(3):128-34.

11. Ismanto $H$. Pengendalian Vektor Dengan Pengubahan Lingkungan. J Litbang Pengendali Penyakit Bersumber Binatang Banjarnegara. 2006;II(Juni).

12. Aswadi M, Hendra. Perencanaan pengelolaan sampah di perumahan tavanjuka mas. Mektek. 2011;13(2):99-110.

13. Ogundele OM, Rapheal OM, Abiodun AM. Effects of Municipal Waste Disposal Methods 
on Community Health in Ibadan - Nigeria. Polytechnica. 2018;1(1-2):6172.https://doi.org/10.1007/s41050-018-0008-y

14. Alam P, Ahmade K. Impact of Solid Waste on Health and the Environment. Int J Sustain Dev ... [Internet]. 2013;2(1):165-8.

15. Darmawati AT, Sunarsih E, Trisnaini I. Hubungan Faktor Kondisi Fisik Rumah dan Perilaku dengan Insiden Pneumonia pada Anak Balita di Wilayah Kerja Puskesmas Yosomulyo Kota Metro. J Ilmu Kesehat Masy. 2016;7:6-13.

16. Boubekri M, Cheung IN, Reid KJ, Wang $\mathrm{CH}$, Zee PC. Impact of windows and daylight exposure on overall health and sleep quality of office workers: A case-control pilot study. J Clin Sleep Med. 2014;10(6):60311.https://doi.org/10.5664/jcsm.3780

17. Boubekri M, Lee J, MacNaughton P, Woo M, Schuyler L, Tinianov B, et al. The Impact of Optimized Daylight and Views on the Sleep Duration and Cognitive Performance of Office Workers. Int $\mathbf{J}$ Environ Res Public Heal. 2020;17.https://doi.org/10.3390/ijerph17093219

18. Saghawari TO, Rantetampang AL, Mallongi A. The Risk Factors of Dengue Hemorrhagic Fever Incidence in Sorong City Papua Barat Province. Galore Int J Heal Sci Res. 2019;4(1):81-90.

19. Muda AS, Haqi DN. Determinan Yang Berhubungan Dengan Keberadaan Jentik Di Kelurahan Rangkah Buntu , Surabaya Determinant Factor of Larva Existence on the Rangkah ,. Indones J Heal Promot Heal Educ. 2019;7(1):22-

33.https://doi.org/10.20473/jpk.V7.I1.2019.2233

20. Bhat LD, Nayar KR, Moosan H, Nair S, Shaffi M. Hand-Washing and Public Health. 2015;(1956):19-21.

21. Haque M. Handwashing in averting infectious diseases: Relevance to COVID-19. J Popul Ther Clin Pharmacol. 2020;27(Special Issues 1):e3752.https://doi.org/10.15586/jptcp.v27SP1.711

22. Sanaz Ahmadpoor Samani, Soodeh Ahmadpoor Samani. The Impact of Indoor Lighting on Students' Learning Performance in Learning Environments: A knowledge internalization perspective. Int $\mathrm{J}$ Bus Soc Sci [Internet]. 2012;3(24):127-36.

23. Sleegers PJC, Moolenaar NM, Galetzka M, Pruyn A, Sarroukh BE, Van Der Zande B. Lighting affects students' concentration positively: Findings from three Dutch studies. Light Res Technol. 2013;45(2):15975.https://doi.org/10.1177/1477153512446099

24. National Renewable Energy Laboratory. Residential Indoor Temperature Study [Internet]. Alexandria: U.S. Department of Energy; 2017.

25. Fernstrom A, Goldblatt M. Aerobiology and Its Role in the Transmission of Infectious Diseases. $\mathrm{J}$ Pathog. 13.https://doi.org/10.1155/2013/493960

26. Memarzadeh F. Literature Review: Room Ventilation and Airborne Disease Transmission. Am Soc Healthc Eng. 2013;ASHE catal(May):154. 